\title{
PENGARUH KUALITAS BAHAN BAKU TERHADAP KUALITAS HASIL PRODUKSI (Studi Pada CV Mebel Bima Karya Kabupaten Blitar)
}

\author{
Nurul Farida, SE.,MM \\ Dosen Fakultas Ekonomi Universitas Islam Balitar \\ Email.nurulfarida27@yahoo.co.id
}

\begin{abstract}
Abstrak
Keberhasilan suatu perusahaan dalam pengolahan bahan baku tergantung dari upaya perusahaan untuk mencari dan memilih dengan teliti bahan baku yang akan digunakan dalam proses produksi. Dengan adanya bahan baku dengan kualitas baik maka maka akan memberikan kualitas keluaran yang baik pula. Penelitian ini bertujuan untuk mengetaui sejauh mana bahan baku berpengauh terhadap kualitas produk.

Adapun metode analisis data yang digunakan penulis dalam penelitian ini adalah analisis regresi berganda. Dimana yang menjadi variabel bebanya yaitu X1 Keindahan, X2 Kekuatan dan variabel Y adalah kualitas produk. dari Berdasarkan uji statistik secara parsial, dapat disimpulkan bahwa kekuatan dalam kualitas bahan baku memiliki pengaruh yang signifikan terhadap kualitas hasil produksi. Penjelasan secara teoritis, dikatakan semakin baik kualitas kekuatan dalam kualitas bahan baku, maka hasil produksi pun akan semakin berkualitas.
\end{abstract}

\section{Kata Kunci : Keindahan, Kekuatan dan Kualitas Produk}

\section{Pendahuluan.}

Sejalan dengan lajunya pertumbuhan perekonomian diindonesia, semakin terasa adanya aktifitas usaha kearah persaingan untuk meraih pangsa pasar yang terbesar. Perusahaan - perusahaan baru yang menawarkan berbagai macam produk bermunculan, sehingga tidak terelakkan timbulnya persaingan yang semakin kompetitif.

Perkembangan dunia bisnis semakin pesat dan keadaan perekonomian dunia pun dapat berubah, dimana dalam hal ini baik langsung maupun tidak langsung akan mempengaruhi keadaan perusahaan. Pimpinan perusahaan harus mengikuti perkembangan jaman dan perubahan yang terjadi pada segala aspek dilingkungan sehingga mampu melanjutkan kelangsungan hidup perusahaan itu sendiri. Perusahaan memperoleh laba jika hasil penjualan lebih besar dari harga yang dikeluarkan untuk proses produksi. Dengan berkembangnya perusahaan otomatis organisasi perusahaan ikut berkembang. Hal ini akan mengakibatkan masalah yang timbul didalam perusahaan akan semakin luas dan kompleks. Apabila keadaan tersebut didiamkan tentu saja akan keterbatasan manajemen dalam mengatur system kerja dan finansial perusahaan. Untuk dapat memecahkan masalah tersebut, tentunya pimpinan perusahaan dalam mengambil kebijakan tidak hanya melihat dan menganalisis isternal perusahaan saja, tetapi juga eksternal perusahaan. Semakin berkembang teknologi dan peradaban manusia, maka cara berfikir mereka sebagai konsumen membeli barang ataupun jasa tidak hanya untuk memenuhi kebutuhan saja, tetapi mereka sudah mulai menggunakan pertimbangan mengenai kualitas barang atau jasa yang mereka beli serta pertimbangan mengenai harga. Kecepatan untuk 
memenuhi permintaan pasar dengan kualitas produk dan harga bersaing inilah yang diharapkan menghentikan persaingan.

Dengan adanya bahan baku dengan kualitas baik maka akan maka akan memberikan kualitas keluaran yang baik pula. Keberhasilan suatu perusahaan dalam pengolahan bahan baku tersebut tergantung dari upaya perusahaan untuk mencari dan memilih dengan teliti bahan baku yang akan digunakan dalam proses produksi. Dengan kualitas bahan baku yang semakin baik maka akan mengurangi terjadinya kesalahan produksi maupun proses produksi ulang. Untuk mendapatkan bahan baku yang bermutu baik maka dilakukan pengujian atau pengetesan bahan baku, maka dapat diketahui bahan baku yang sesuai dengan kriteria yang ditetap kan oleh perusahaan dan mana yang tidak sesuai. Bila mutu bahan baku sesuai dengan standar yang ditetapkan maka diharapkan adanya produk yang bermutu baik pula.

Ketersediaan bahan baku menjadi bagian yang paling penting didalam proses produksi dan harus ada pada saat dibutuhkan, selain itu faktor ysng paling penting adalah ketersediaan mesin - mesin yang siap diopersaikan untuk mengubah bahan baku menjadi bahan jadi yang siap dijual. Semua itu memerlukan pengawasan dan pengendalian dalam penggunaan dan pengoperasiannya agar perusahaan dapat berproduksi sesuai dengan rencana yang telah ditetapkan.

Elemen yang paling penting agar perusahaan dapat merencanakan dan mengendalikan biaya produksi adalah bahan baku, sehingga sesuai dengan tujuan diadakan perencanaan dan pengendalian serta perusahaan dapat menyelenggarakan persediaan bahan baku yang tepat.

Kualitas adalah tolak ukur relative terhadap perbaikan (don R. Hansen dan Maryane M. Mowen, 2001 : 963). Kualitas produk merupakan keseluruhan karakteristik produk atau jasa dari rancangan sampai pengiriman produk tersebut kepelanggan sesuai dengan yang diharapkan tanpa melalui pembuatan yang berulang - ulang. Tanpa memperhatikan kualitas produk yang dihasilkan, itu berarti mematikan harapan bagi perusahaan dimasa yang akan datang, sehingga perusahaan akan menghasilkan produk yang lebih rendah kualitasnya. Untuk memperoleh produk dengan kualitas yang sesuai dengan yang distandarkan, perusahaan harus mengadakan pengawasan bahkan sebelum proses produksi dimulai. Jadi kualitas produk yang tinggi merupakan kunci keunggulan bersaing, dimana kualitas bahan bakunya bisa di upayakan dengan cara mengadakan seleksi sumber bahan, pemeriksaan penerimaan barang dan penjagaan gudang bahan bahan baku perusahaan (Agus ahyari, 1990 : 264).

\section{Rumusan masalah}

Dari latar belakang diatas maka rumusan masalah dari penelitian ini yaitu:

1. Apakah kualitas bahan baku berpengaruh terhadap hasil produksi?

2. Seberapa besar pengaruh bahan baku mempengaruhi kualitas produk?

\section{Batasan masalah}

Untuk lebih fokos dan memperjelas dari permasalahan yang dibahas ini maka dalam penelitian ini perlua danya batasan masalah. Dengan melihat judul dari penelitian ini maka batasan masalah dari penelitian ini adalah kualitas bahan baku yang digunakan serta proses produksi dari bahan baku menjadi barang jadi yang mempunyai kualitas yang baik.

\section{Tujuan penelitian}

Tujuan dari penelitian adalah : 
1. Untuk mengetahui apakah kualitas bahan baku mempengaruhi kualitas hasil produksi perusahaan pengolahan kayu (mebel) CV. BIMA KARYA Blitar.

2. Untuk mengetahui sejauh mana peran kualitas bahan baku terhadap kualitas produksi pengolahan kayu (mebel) CV. BIMA KARYA Blitar.

\section{METODOLOGI PENELITIAN.}

\section{Jenis Penelitian}

Dalam penelitian ini peneliti menggunakan pendekatan statistik kuantitatif dengan Analisis Korelasi sederhana atau sering disebut dengan Korelasi Pearson (Pearson Product Moment) tujuannya yaitu untuk mengetahui pengaruh saluran distribusi terhadap volume penjualan.

\section{Jenis dan Sumber Data}

Data yang diperoleh dari pengumpulan data berguna untuk mendukung keakuratan penyajian suatu penelitian dan sangat menentukan hasilnya.

1). Jenis data

1. Data kualitatif.

Yaitu data yang tidak berupa angka-angka melainkan data yang berupa uraian yang terdiri dari data mengenai gambaran umum seperti: gambaran umum obyek yang diteliti, struktur organisasi, job diskription dan sebagainya.

2. Data kuantitatif

\section{2). Sumber Data}

Yaitu data yang dapat dinyatakan dalam bentuk angka.

Dalam penelitian ini peneliti memerlukan data-data sebagai sumber penelitian untuk dapat diolah lebih lanjut menurut sumbernya data dibedakan menjadi 2 yaitu :

\section{Data Primer}

Data primer adalah data yang diperoleh secara langsung dari lokasi dengan cara wawancara atau interview dan pengamatan langsung di lokasi penelitian.

\section{Data Sekunder}

Data sekunder adalah data yang diperoleh dari pengumpulan dokumen atau mencari informasi yang dibutuhkan melalui data-data yang telah tersusun dan berkaitan erat dengan masalah yang akan diteliti dari literatur.

\section{Teknik Pengumpulan Data}

Adapun teknik pengumpulan data yang penulis gunakan adalah sebagai berikut:

1. Interview (wawancara), proses pengumpulan data yang dilakukan dengan cara tanya jawab sambil bertatap muka secara langsung dengan pimpinan perusahaan atau instansi dan Karyawan.

2. Kuisoner,

Yaitu pengumpulan data yang dilakukan dengan cara memberi seperangkat pertanyaan tertulis kepada responden untuk dijawab seputar masalah penelitian.

3. Studi Pustaka yaitu dengan menggunakan buku-buku dan literatur-literatur untuk mendukung penelitian agar lebih kuat

4. Dokumentasi 
Yaitu Cara pengumpulan data dengan mencatat dokumen yang ada di perusahaan sesuai dengan obyek yang diteliti.

\section{Variabel Penelitian}

1. Variabel bebas $(X)$ Yaitu kualitas bahan baku

$\mathrm{X}_{1}=$ keindahan

Keindahan dalam mebel Bima Karya ini adalah Bentuk bahan baku $\mathrm{g}$ digunakan.

$\mathrm{X}_{2}$ = kekuatan

Yang menjadi kekuatan dalam produk ini adalah usia bahan baku dan jenis bahan baku yang digunakan yaitu kayu jati.

2. Variabel terikat $(\mathrm{Y})$ yaitu Kualitas hasil produksi.

Adalah salah satu yang menentukan kualitas hasil produksi adalah Bentuk atau modelny,rapi, Halus, ukir2anya menarik punya seni dan daya tarik.

Maka di C V Mebel Bima Karya ini dalam segi kualitas dibedakan ada jenis

kualitas bagus, kualitas sedang dan kulaitas rendah.

\section{Teknik Analisa Data}

Metode analisis data adalah suatu metode yang digunakan untuk mengolah hasil penelitian guna memperoleh suatu instrumen dan kesimpulan. Adapun metode analisis data yang digunakan penulis dalam penelitian ini adalah analisis regresi berganda.

Teknik analisis analisis regresi berganda digunakan untuk mengetahui pengaruh antara variabal bebas dan variabel terikat.

$$
\begin{array}{ll}
Y=a+b_{1} X_{1}+b_{2} X_{2}+e \\
\text { Keterangan : } \\
\mathrm{Y} \quad=\text { variabel kualitas hasil produksi } \\
\mathrm{a} \quad=\text { bilangan konstanta } \\
\mathrm{b}_{1} \quad=\text { koefisiensi regresi keindahan } \\
\mathrm{b}_{2} \quad=\text { koefisiensi regresi kekuatan } \\
\mathrm{X}_{1} \quad=\text { keindahan } \\
\mathrm{X}_{2} \quad=\text { kekuatan } \\
\mathrm{E} & =\text { variabel lain yang tidak diteliti }
\end{array}
$$

\section{Uji Koefisien Determinasi $\left(R^{2}\right)$}

Koefisien determinasi adalah salah satu nilai statistik yang dapat digunakan untuk mengetahui apakah ada pengaruh antara dua variabel. Nilai koefisien dari determinasi menunjukan persentase variasi nilai variabel yang dapat dijelaskan oleh persamaan regresi yang dihasilkan (Al-Gifari, 2001).

Uji F

Untuk mengetahui pengaruh variabel bebas terhadap variabel terikat secara simultan (bersama-sama) digunakan uji $\mathrm{F}$ dengan persamaan :

$$
\begin{aligned}
& F_{\text {hitung }}=\frac{R^{2} / k}{\left(1-R^{2}\right) /(n-k-1)} \\
& \text { Keterangan : } \\
& \mathrm{R}^{2}=\text { koefisien determinasi }
\end{aligned}
$$


$\mathrm{k}=$ jumlah variabel bebas

$\mathrm{n}$ = jumlah sampel

Pernyataan :

Ho $: b_{1}, b_{2}, b_{3}=0$

Berarti tidak ada pengaruh antara variabel bebas secara simultan terhadap variabel terikat.

$H a=b_{1}, b_{2}, b_{3} \neq 0$

Berarti ada pengaruh antara variabel bebas secara simultan terhadap variabel terikat.

Kriteria uji F :

Ho ditolak jika $F$ hitung $\leq F$ tabel

Ho ditolak jika $F$ hitung $\geq F$ tabel

\section{Uji Parsial (Uji t)}

Uji $\mathrm{t}$ digunakan untuk mengetahui pengaruh masing-masing variabel independen (kekuatan (X1 dan keindahan (X2) terhadap variabel dependen (kualitas hasil produksi $(Y)$.

Rumus uji $\mathrm{t}$

$$
t_{\text {hitung }}=\frac{r s \sqrt{n-2}}{\sqrt{1-r s^{2}}}
$$

\section{Hasil Penelitian}

Untuk mengetahui pengaruh kualitas bahan baku keindahan $\left(\mathrm{X}_{1}\right)$ dan kekuatan $\left(\mathrm{X}_{2}\right)$, terhadap kualitas hasil produksi maka digunakan analisis regresi linier berganda. Berdasarkan hasil perhitungan yang telah dilakukan dengan program statistik SPSS for Windows Release 13.0 diperoleh hasil sebagai berikut

Tabel 1

Regresi Linier Berganda

Coefficients a

\begin{tabular}{|c|c|c|c|c|c|c|}
\hline \multirow{2}{*}{\multicolumn{2}{|c|}{ Model }} & \multicolumn{2}{|c|}{$\begin{array}{l}\text { Unstandardized } \\
\text { Coefficients }\end{array}$} & \multirow{2}{*}{$\begin{array}{c}\begin{array}{c}\text { Standardized } \\
\text { Coefficients }\end{array} \\
\text { Beta }\end{array}$} & \multirow[b]{2}{*}{$\mathrm{t}$} & \multirow[b]{2}{*}{ Sig. } \\
\hline & & B & Std. Error & & & \\
\hline \multirow[t]{3}{*}{1} & (Constant) & -1.141 & 4.664 & & .245 & .814 \\
\hline & keindahan & -.592 & .227 & .656 & -2.606 & .035 \\
\hline & kekuatan & 1.822 & .344 & 1.334 & 5.295 & .001 \\
\hline
\end{tabular}

a. Dependent Variable: hasil produksi

Sehingga diperoleh persamaan regresinya sebagai berikut :

$$
Y=-1,141+-592\left(X_{1}\right)+1,822\left(X_{2}\right)
$$

Dimana : 
a $\quad=-1,1141$ angka tersebut menunjukkan hasil produksi bila keindahan dan kekuatan diabaikan

$b_{1}=-0,592$ artinya jika nilai faktor keindahan mengalami peningkatan sebesar

1

maka hasil produksi akan bertambah $-0,592$

$b_{2}=1,822$ artinya jika nilai faktor kekuatan mengalami peningkatan sebesar 1 , maka hasil produksi akan bertambah 1,822

Hasil analisis diatas menunjukkan bahwa faktor keduanya mempunyai pengaruh yang positif terhadap hasil produksi, namun faktor kekuatan lebih besar pengaruhnya dibanding faktor keindahan.

\section{Uji R}

Reliabilitas menunjukkan pada suatu pengertian bahwa suatu instrumen cukup dapat dipercaya untuk menguji ketepatan di antara butir-butir pertanyaan dalam instrumen penelitian. Adapun hasil perhitungan yang didapat dengan menggunakan program SPSS terlihat pada tabel berikut:

Tabel 2

Uji Reliabilitas

\begin{tabular}{|l|c|c|c|c|}
\hline \multicolumn{1}{|c|}{ Variabel } & $\alpha$-hit & Tanda & $\alpha$-batas & Keterangan \\
\hline Keindahan & 0,587 & $>$ & 0,5 & Reliabel \\
\hline Kekuatan & 0,959 & $>$ & 0,5 & Reliabel \\
\hline hasil produksi & 0,593 & $>$ & 0,5 & Reliabel \\
\hline
\end{tabular}

Sumber: Data Primer Diolah

Dari hasil yang didapat pada tabel di atas maka dapat dikatakan bahwa data yang digunakan reliabel. Sehingga dari pengujian validitas dan reliabilitas disimpulkan kesemua data valid dan reliabel.

\section{Uji F}

Tabel 3

ANOVA b

\begin{tabular}{|ll|r|r|r|r|r|}
\hline Model & & \multicolumn{1}{c|}{$\begin{array}{c}\text { Sum of } \\
\text { Squares }\end{array}$} & df & Mean Square & F & Sig. \\
\hline 1 & Regression & 203.462 & 2 & 101.731 & 41.836 & $.000^{\mathrm{a}}$ \\
& Residual & 41.338 & 17 & 2.432 & & \\
& Total & 244.800 & 19 & & & \\
\end{tabular}

a. Predictors: (Constant), kekuatan, keindahan

b. Dependent Variable: hasil produksi

Sumber : data diolah (output program SPSS 13.0)

Langkah-langkah untuk melakukan uji F sebagai berikut :

1). Hipotesis

Ho = kualitas bahan baku secara simultan tidak mempunyai pengaruh yang signifikan terhadap kualitas hasil produksi

$\mathrm{Ha}=$ kualitas bahan baku secara simultan mempunyai pengaruh yang signifikan terhadap kualitas hasil produksi

2). Tingkat Signifikansi

Tingkat signifikansi yang digunakan adalah $0,05(a=5 \%)$ dan pada 
tabel 4.2.3.2 tingkat signifikansi yang diperoleh sebesar 0,000 atau $0,0 \%$. Artinya variabel independen berpengaruh terhadap variabel dependen dengan tingkat signifikansi sebesar $0.0 \%$.

3). Menentukan $\mathrm{F}$ hitung berdasarkan angka yang terdapat dalam tabel diatas sebesar $0,0 \%$. Sedangkan, berdasarkan rumus yaitu :

$$
\begin{aligned}
\text { F hitung } & =\frac{\frac{\mathrm{R}^{2}}{\mathrm{k}}}{\left[\frac{1-\mathrm{R}^{2}}{\mathrm{n}-\mathrm{k}-1}\right]} \\
& =\frac{\frac{0,831}{2}}{\left[\frac{1-0,831}{20-2-1}\right]} \\
& =\frac{0,4155}{0,00994} \\
& =41,8008
\end{aligned}
$$

Jadi diketahui Nilai $F_{\text {hitung }}>F_{\text {tabel }}(41,800>3,591)$

Secara teoritis, kualitas bahan baku memiliki pengaruh yang signifikan terhadap kualitas hasil produksi perusahaan.

\section{Uji T}

\begin{tabular}{|c|c|c|c|c|c|c|}
\hline \multirow[b]{2}{*}{ Mod } & & \multicolumn{2}{|c|}{$\begin{array}{l}\text { Unstandardized } \\
\text { Coefficients }\end{array}$} & \multirow{2}{*}{$\begin{array}{c}\begin{array}{c}\text { Standardized } \\
\text { Coefficients }\end{array} \\
\text { Beta }\end{array}$} & \multirow[b]{2}{*}{$\mathrm{t}$} & \multirow[b]{2}{*}{ Sig. } \\
\hline & & B & Std. Error & & & \\
\hline \multirow[t]{3}{*}{1} & (Constant) & -1.141 & 2.993 & & -.381 & .708 \\
\hline & keindahan &. .592 & .146 & $=656$ & -4.061 & .001 \\
\hline & kekuatan & 1.822 & .221 & 1.334 & 8.251 & .000 \\
\hline
\end{tabular}

Hasil uji t dapat dilihat pada output coefficients dari hasil analisis regresi linier berganda berikut ini:

Tabel 4

Coefficients a

a. Dependent Variable: hasil produksi

Sumber data : data diolah (output program SPSS 13.0)

\section{Pengujian koefisien regresi variabel keindahan}

berdasarkan tabel di atas, maka t hitung variabel keindahan sebesar $-4,061$. Tabel distribusi t dicari pada $a=5 \%: 2=2,5 \%$ (uji 2 sisi) dengan derajat kebebasan (df) $=\mathrm{n}-\mathrm{k}-1$ atau $10-2-1=7$. Dengan pengujian 2 sisi (signifikansi $=0,025$ ) hasil diperoleh untuk $t$ tabel sebesar 1,734.

Kriteria pengujian

Ho diterima jika - $t$ tabel $\leq t$ hitung $\leq t$ tabel

Ho ditolak jika -t hitung $<-t$ tabel atau $t$ hitung $>t$ tabel

Nilai $t$ tabel $>t$ hitung $(1,734>-4,061)$

Jadi, berdasarkan uji t statistik secara parsial, dengan memerhatikan 
perbandingan t hitung yang lebih kecil dari t tabel dan tingkat signifikansi yang lebih kecil yakni $0,1 \%$ dari standar signifikansi sebesar $5 \%$, maka dapat disimpulkan bahwa Ho diterima atau keindahan secara parsial berpengaruh signifikan terhadap kualitas produksi.

\section{Pengujian koefisien regresi variabel kekuatan.}

Berdasarkan tabel di atas, maka $\mathrm{t}$ hitung variabel kekuatan sebesar 8,251. Tabel distribusi t dicari pada $a=5 \%: 2=2,5 \%$ (uji 2 sisi) dengan derajat kebebasan (df) $=n-k-1$ atau $20-2-1=17$. Dengan pengujian 2 sisi (signifikansi $=0,025$ ) hasil diperoleh untuk $t$ tabel sebesar 1,734 .

Kriteria pengujian

Ho diterima jika $-\mathrm{t}$ tabel $\leq \mathrm{t}$ hitung $\leq \mathrm{t}$ tabel

Ho ditolak jika $-t$ hitung $<-t$ tabel atau $t$ hitung $>t$ tabel

Nilai t hitung $>$ t tabel $(8,251 .>1,734)$

Jadi, berdasarkan uji statistik dengan pengujian $\mathrm{t}$, maka Ho ditolak atau $\mathrm{Ha}$ diterima. Sehingga dapat disimpulkan bahwa kekuatan secara parsial berpengaruh signifikan terhadap kualitas hasil produksi.

\section{Kesimpulan.}

Berdasarkan uji statistik secara parsial, dapat disimpulkan bahwa kekuatan dalam kualitas bahan baku memiliki pengaruh yang signifikan terhadap kualitas hasil produksi. Penjelasan secara teoritis, dikatakan semakin baik kualitas kekuatan dalam kualitas bahan baku, maka hasil produksi pun akan semakin berkualitas. Hal ini dibuktikan dengan tingkat signifikansi yang lebih kecil dari 0,05 atau 5\% yang merupakan standar signifikansi, yaitu sebesar 0,000 atau $0,0 \%$, dan hasil perbandingan antara $t$ hitung dan $t$ tabel yang menunjukkan bahwa t hitung sebesar 8,251 lebih besar dari pada t tabel yakni 1,734; dan berdasarkan kriteria, apabila $t$ hitung > t tabel maka disimpulkan $\mathrm{Ha}$ diterima atau variabel independen memiliki pengaruh yang signifikan terhadap variabel dependen.

\section{Daftar Pustaka.}

Agus ahyari , DRS. (1987), manajemen produksi pengendalian produksi edisi ke 4, Yogyakarta, BPFE

Alan swann (1997), the new graphic design school new burlengtor book,London, h.106

Elwoods s. buffa (1983), manajemen produksi/operasi jilid 1 edisi 6, Jakarta,erlangga

Vincent gaspersz (2011), Ekonomi manajerial (managerial economics), Jakarta : gramedia pustaka.

Supriyanto, Agus dan Masruchah, Ida. (2000). Manajemen Purchasing, Strategi Pengadaan dan Pengelolaan Material untuk Perusahaan Manufakturing. Jakarta. PT Elex Media Komputindo.

Widayat dan Amirullah. (2002). Riset Bisnis. Yogyakarta. Graha Ilmu Indrajad, Eko Ricardus dan Djokopranoto, Ricardus. (2005). Strategi Pembelian dan Supply Chain. Jakarta. PT Gramedia.

Subagyo, Pangstu. (2000). Manajemen Operasi. Yogyakarta. BPFE Yogyakarta 